\title{
A new species of leafy calamite stem from the Pennsylvanian (Bolsovian) of the South Wales Coalfield
}

\author{
BARRY A. THOMAS \\ Institute of Biological, Environmental and Rural Sciences, Aberystwyth University, Penglais, Aberystwyth, \\ Ceredigion, SY23 1NP, UK; e-mail: bat@aber.ac.uk
}

Received 22 February 2020; accepted for publication 8 June 2020

\begin{abstract}
Large leafy calamite stems are very rare in the fossil record. One such leafy stem is described as a new species, Calamites cambrensis, from shales above the No 2 Rhondda Seam in the Bolsovian of the South Wales Coalfield.
\end{abstract}

KEYWORDS: Calamites foliage, adpression, Sphenophyta, No 2 Rhondda coal seam, South Wales, Bolsovian, Pennsylvanian

\section{INTRODUCTION}

Sphenophytes have existed since the Late Devonian (Taylor et al., 2009). The largest of them were the Pennsylvanian calamites, whose fossil fragments are abundant in Pennsylvanian sediments of Europe and North America while in China they continue from the Pennsylvanian to the Permian. The calamites were important components of the coal-forming plant communities and lived in the wetter parts of the palaeotropical belt, with many of them flourishing around the fringes of lakes. Fragments of the plants are commonly found preserved as adpressions in Pennsylvanian sediments, the commonest fragments being stems called Calamites Sternberg, as are the whole plants. Their whorled leaves are described as Annularia Sternberg or Asterophyllites Brongniart, and their cones usually as Calamostachys Schimper or Palaeostachya Weiss. Stems preserved as petrifactions are assigned to the genera Arthropytis Goeppert, Arthroxylon Reed or Calamodendron Brongniart (Andrews, 1952; Reed, 1952). Many species of Calamites stems developed secondary wood enabling the plants to grow to heights of at least 10-20 m (Scott, 1920;
Hirmer, 1927; Boureau, 1964; Rössler and Noll, 2006; Taylor et al., 2009). Some calamites were of dwarf size and probably only about $1.5 \mathrm{~m}$ in height when fully mature (Libertín et al., 2009). The vertical stems of most species grew from creeping underground rhizomes, although some species such as $C$. gigas Brongniart are known to have grown as single plants (Bartell, 1980). Calamites branched, resulting in small tree-sized plants looking like giant Callistemon bottle brushes

The external features of Calamites show a regular pattern of nodes separated by internodal areas. Branches and leaves were developed at the nodes, both being shed during life from the older parts of the plants. The leaves left rings of small scars just above the nodes, while the branches left large round or oval scars at the nodes. The internodal areas are ornamented with alternating longitudinal ridges and grooves which are offset at each node.

Sometimes the basal parts of Calamites are found as three-dimensionally preserved vertical casts in their original positions of growth. Such casts can represent their external features 
or can be pith-casts of their internal hollow centres. Thomas (2013: table 1) discussed the problem of distinguishing between the two, and summarised and compared the distinctive features of stem casts and pith casts.

Although there is a limit to the information that Calamites adpression fossils can give us about the systematics of the parent plants, they have been the subject of a number of taxonomic studies (e.g. Stur, 1887; Jongmans, 1911; Jongmans and Kukuk, 1913; Kidston and Jongmans, 1917; Gothan et al., 1959; Crookall, 1969). Calamites species are distinguished by the length/breadth ratio of the internodal areas, the number of leaf scars and branch scars per node, and the number of internodal ridges and furrows.

Calamites stems that retain their leaves are known, but these are rare and more often found in ironstone nodules (Thomas, 2013: fig. 13). However, there are very few examples known of leafy large adpression stems; this account deals with such a new specimen.

\section{MATERIALS AND METHODS}

The specimen (No. 26.277G6, National Museum of Wales, Cardiff) came from above the No 2 Rhondda Seam (Bolsovian), Ynyshir Colliery in the Rhondda
Fach, Rhondda Cynon Taff, South Wales (Figs 1, 2). It is a stem fragment showing three nodes, with the internodal areas spanning $27-40 \mathrm{~mm}$ long and $\sim 100 \mathrm{~mm}$ in incomplete width. Each node bears leaves $\sim 2-4 \mathrm{~mm}$ apart, each leaf being $\sim 42 \mathrm{~mm}$ long and $1 \mathrm{~mm}$ broad just above their $2 \mathrm{~mm}$ broad bases. The way that the leaves appear to be covered by the internode areas above suggests that the specimen is being viewed from the inner surface. There are no branches or branch scars. There are no ridges and furrows in the internodal areas, although the surface is ornamented with fine horizontal reticulate striations (Figs 3, 4). This lack of the more normal ridgeand-furrow ornamentation might be the result of the positioning of the stem; however, because the compression is thin enough to show the leaves, it seems unlikely that ridges and furrows would not show through as well.

\section{SYSTEMATIC PALAEONTOLOGY}

\section{Calamites cambrensis sp. nov.}

Figs 3, 4

1884 Calamites varians var insignis Weiss 1884 pl. 1, figs $4,5$.

1910 Calamites insignis Renier 1910 pl. 42.

1911 Calamites varians insignis Jongmas 1911, figs 77, 77a.

Stem with internodes $27-40 \mathrm{~mm}$ long, at least $100 \mathrm{~mm}$ broad, ornamented with fine horizontal reticulation. Nodes leafy. Individual leaves

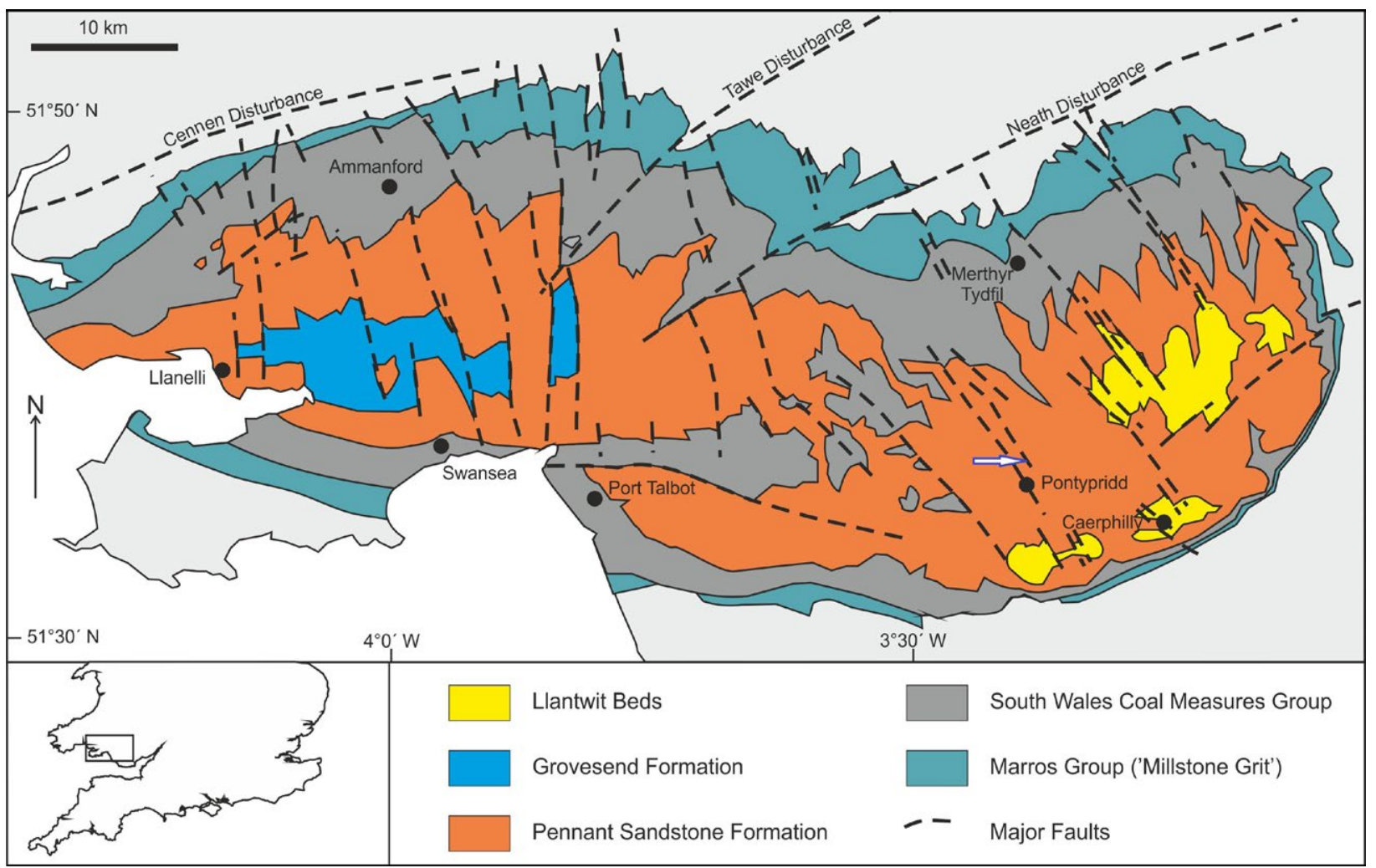

Fig. 1. The South Wales Coalfield, showing the position of the Ynyshir Colliery. From Cleal et al. (2010), with permission 


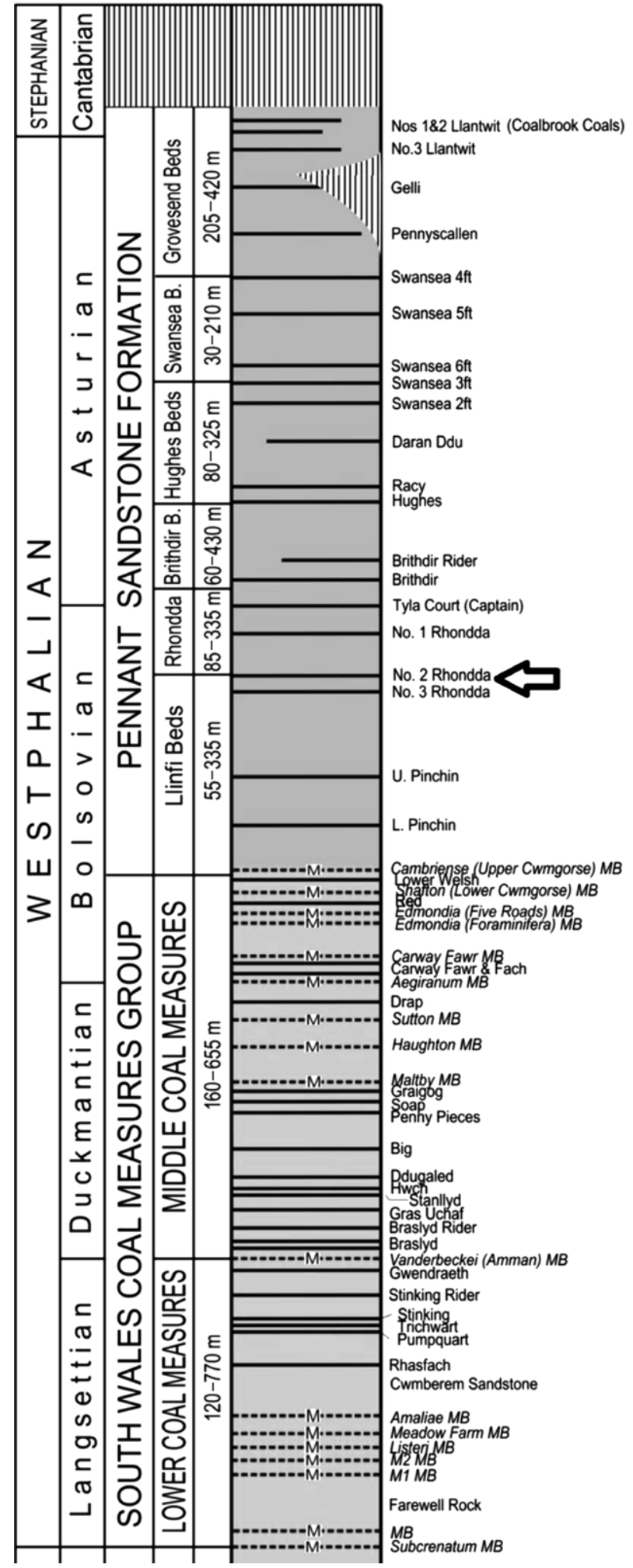

Fig. 2. Pennsylvanian stratigraphy of the South Wales Coalfield at its fullest development in the central part of the basin. From Cleal et al. (2010), with permission. The arrow indicates the Rhondda No 2 seam

$\sim 42 \mathrm{~mm}$ long, tapering from $2 \mathrm{~mm}$ bases to pointed apices.

Type specimen. No. 26.277G6, National Museum of Wales, Cardiff, from above the No 2 Rhondda Seam (Bolsovian), Ynyshir

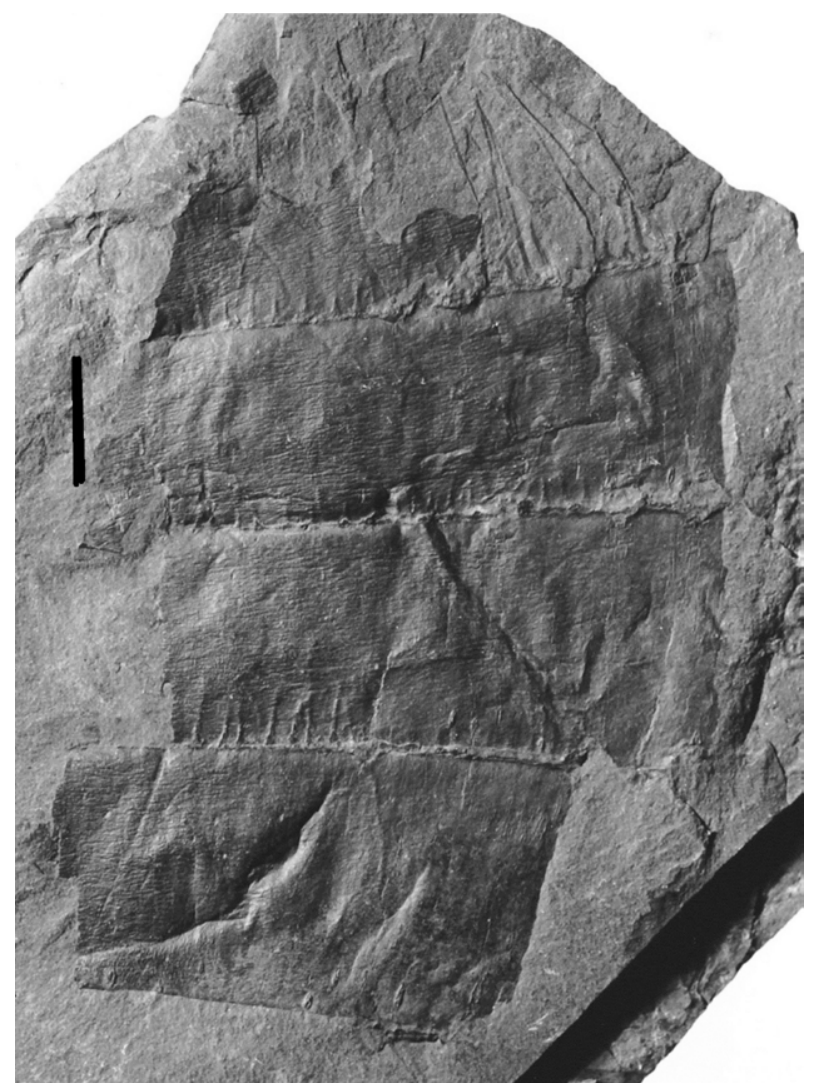

Fig. 3. Calamites cambrensis sp. nov., no. 26.277G6, National Museum of Wales, Cardiff. Scale bar $=20 \mathrm{~mm}$

Colliery, Rhondda Fach, Rhondda Cynon Taff, South Wales.

Derivation of name.cambrenis, Latin for 'of Wales'.

\section{COMPARISON}

Specimens identical to Calamites cambrensis are leafy shoots that were called $C$. varians var insignis by Weiss (1884). The Weiss diagnosis for C. varians var. insignis was clearly based on the specimens figured by Germar (1847: pl. 20, figs 2,3 ) as C. varians, whose specimens are stem adpressions showing the outer surface with small branch scars emitted from the nodes. The first person to make this variety a species, Calamites insignis, was Renier (1910), showing a specimen very like C. cambrensis, with a wrinkled surface and what looks like short leaves attached at the nodes. However, the name "Calamites insignis" was preoccupied by Calamites insignis Sauveur, 1848. The type of this species is a totally unidentifiable stem and was reproduced by Jongmans (1911: fig. 75). Neither Weiss nor Renier made reference to the Sauveur fossil, and as their 

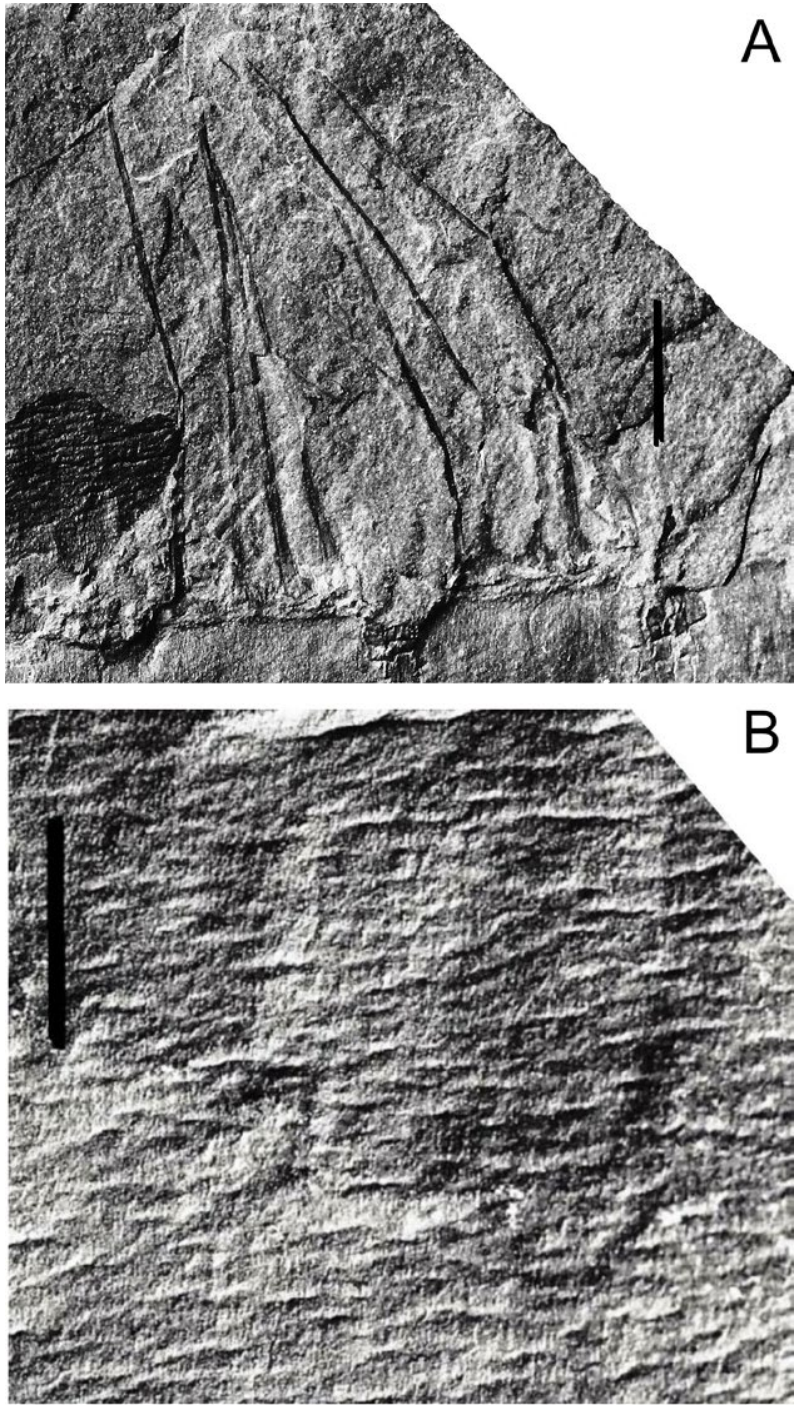

Fig. 4. Calamites cambrensis sp. nov. A. Node with leaves. Scale bar $10 \mathrm{~mm}$.; B. Detail of internode showing horizontal striations. Scale bar $=4 \mathrm{~mm}$

fossils are quite different from that specimen, they were clearly not adopting Sauveur's name for their fossils. Their species must therefore be regarded as a later homonym of $C$. insignis Sauveur and suppressed. Calamites insignis cannot be used for the South Wales specimen because the name was pre-occupied; hence they have been referred to $C$. cambrensis sp. nov.

Another similar species is Calamites ohlsbachensis Sterzel 1907, described from the Ottweiler Schichten, Ottweiler Group (Stephanian) of Hinterohlsbach, Baden, Germany (Geological Institute, Freiburg, Germany) and figured by Sterzel (1907: pl. 67, fig. 1, 1a-c), Kidston and Jongmans (1915: pl. 49, figs 3, 4) and Crookall (1969: text-fig. 189). This species has internodal areas similar to those of the South Wales specimen, as they are broader than long and with no obvious vertical ribs. However, the surface is covered with fine vertical striations (horizontal in C. cambrensis), but more importantly there are no leaves at the nodes.

One leafy Calamites has been described from an ironstone nodule found in Duckmantian deposits at Brymbo, Wrexhan in North Wales (Thomas, 2013: fig. 12). The leaves are shorter than those of C. cambrensis and are fused basally. The Brymbo specimen also has ridges and furrows on its internodes, similar to those shown on most adpression species of Calamites.

\section{ACKNOWLEDGEMENT}

I thank Dr Chris Cleal for very helpful discussions.

\section{REFERENCES}

Andrews, H.N., 1952. Some American petrified stems. Annals of the Missouri Botanical Garden 39, 189-218.

Bartell, M., 1980. Calamiten aus dem Oberkarbon und Rotliegenden des Thüringer Waldes. In: Vent, W. (ed.), 100 Jahre Arboretum (1879-1979). pp. 237-258.

Boureau, E., 1964. Traité de paléobotanique, III Sphenophyta, Noeggerathiophyta. Mason et Cie, Paris.

Cleal, C.J., Opluštil, S., Thomas, B.A., Tenchov, Y., 2010 (for 2009). Late Moscovian terrestrial biotas and palaeoenvironments of Variscan Euramerica. Netherlands Journal of Geosciences 88, 181-278.

Crookall, R., 1969. Fossil plants of the Carboniferous rocks of Great Britain [Second section]. Part 5. Memoirs of the Geological Survey of Great Britain, Palaeontology 4, xxi-xxviii, 573-792.

Germar, E.F., 1847. Die Versteinerungen des Steinkohlengebirges von Weltin und Löbejün in Saalkreise, 4, 41-48.

Gothan, W., Leggewie, W., Schönfeld, W., 1959. Die Steinkohlenflora der westlichen paralischen Steinkohlenreviere Deutschlands Lieferung 6 Geologie Jahrbuch 36, 1-90.

Hirmer, M., 1927. Handbuch der Paläobotanik. R. Oldenbourg, Munich and Berlin, pp. 1-708.

Kidston, R., Jongmans, W.J., 1915-1917. Calamites of Western Europe. Mededlingen Rijksopsporing Delfstoffen, 7, 1-207 (1917), pls 1-158 (1915).

Jongmans, W.J., 1911. Anleitung zur Bestimmung der Karbonpflanzen West-Europas mit besonderer Berucksichtigung der in den Niederlanden und den benachbarten Ländern gefundenden oder noch zur erwartenden Arten. I Thallophytae, Equisetales, Sphenophyllales. Craz \& Gerlach, Frieberg.

Jongmans, W.J., Kukuk, P., 1913. Die Calamariaceen des Rheinisch-Westphälischen Kohlenbeckens. Mededeelingen van's Rijks Herbarium, Leiden. 
Libertin, M., Opluštil, S., Pšenička, J., Bek, J., Sýkorova, I., Dašková, J., 2009. Middle Pennsylvanian pioneer plant assemblage buried in situ by volcanic ash-fall, central Bohemia, Czech Republic. Review of Palaeobotany and Palynology 155, 204-233.

Reed, F.D., 1952. Arthroxylon, a redefined genus of calamite. Annals of the Missouri Botanical Garden 39, 173-187.

Renier, A., 1910. Documents pour l'étude de la paléontologie du terraine houiller. $27 \mathrm{pp}$.

Rössler, R., Noll, R., 2006. Sphenopsids of the Permian..Part 1, The largest known anatomically preserved calamite; an exceptional find from the petrified forest of Chemnitz, Germany. Review of Palaeobotany and Palynology 140, 145-162.

Sauver, J.J.D., 1848. Végétaux fossils des terrains houillers de la Belgique, Academie Royle Sciences de Belgique. 1, 2 pp.

Scott, D.H., 1920. Studies in Fossil Botany. A. \& C. Black, London.
Sterzel, J.T., 1907. Die Karbon- und Rotliegenfloren im Grossherzogtum Baden. Mitteilungen Grossherzoglich Badischen Geologischen Landesanstalt 2, 347-892.

Stur, D., 1887. Beiträge zur Kenntnis der Flora der Vorwelt, Bd. ii, Abth. 2. Die Carbon-flora der Schatzalerer Schichten, 2, die Calamarien. Abhandlungen der Kaiserlich-Königlichen Geologischen Reichsanstalt 11-2, 1-240.

Taylor, T.N., Taylor, E.L., Krings, M., 2009. Paleobotany. The study and evolution of fossil plants. Academic Press, Amsterdam.

Thomas, B.A., 2013. In situ stems: preservation states and growth habits of the Pennsylvanian (Carboniferous) calamitaleans based upon new studies of Calamites Sternberg, 1829 in the Duckmantian at Brymbo, North Wales, UK. Palaeontology 57, 21-36.

Weiss, C.E., 1884. Fossile der jüngsten Steinkohlenformation und Beiträge zur fossils. 2 SteinkohlenCalamarian. Abhandlungen zur geologischen Specialkarte von Preussen und den thüringischen Staaten 5(2), 204 pp. 